\title{
Motivation and Autonomy as Predictors of Foreign Language Proficiency among the Iranian Students of Distance vs. Traditional Universities
}

\author{
Farhad Ghorbandordinejad \\ Faculty Member of Shahid Rajaee Teacher Training University, Tehran, Iran \\ E-mail: farhad@srttu.edu
}

Received: 26-05-2014

Accepted: 10-07-2014

Published: 01-11-2014

doi:10.7575/aiac.ijalel.v.3n.6p.113

URL: http://dx.doi.org/10.7575/aiac.ijalel.v.3n.6p.113

\begin{abstract}
This study was conducted to investigate the possible effect of motivation and autonomy on students' English as foreign language proficiency in two universities - Payamenoor (distance) and Islamic Azad universities (traditional)- in the city of Gonbad-e-Kavous. To do so, 152 Azad University students and 144 Payamenoor University students were randomly selected. Three questionnaires each dealing with one of the three variables of motivation, autonomy and foreign language proficiency were distributed among students to collect the required data. Analyzing the data through Multiple Regression and Fisher's $\mathrm{r}$ to $\mathrm{z}$ transformation, the results revealed that there is a significant relationship between motivation and foreign language proficiency in both universities. In regard to autonomy, however, results showed no significant relationship between autonomy and foreign language proficiency in Payamenoor University, while in Azad University this relationship was revealed meaningful and significant. The findings of the current study will inform teachers and curriculum developers of the status of motivation and autonomy in the success of students in their academic performance, pointing out some procedures to enhance this idea.
\end{abstract}

Key words: motivation, autonomy, foreign language proficiency, distance, traditional universities

\section{Introduction}

\subsection{Statement of the problem}

People are different and learn in different ways. That is, there are individual differences in learning. According to Dörnyei (2005), there is a particularly wide variation among language learners in terms of their ultimate success in learning a foreign/second language. These differences have evoked researchers to study individuals in terms of their aptitude, motivation, and attitude towards a foreign/second language.

As an instruction-learning context variable, universities play an important role in teaching and learning various subjects in general and English as a foreign language in particular. Needless to say, universities are mainly consisted of classes, teachers, learners and materials. According to Chastain (1988), students attend their classes with a variety of attitudes toward second or foreign language learning, the class and the teacher. Some of these attitudes enhance their chances for being successful students, and some will have the opposite effect. Among the factors influencing learners' success in any learning situation is "motivation" as defined by Gardner (2001) "The variable, Motivation, refers to the driving force in any situation. In the socioeducational model, motivation to learn the second language is viewed as requiring three elements. First, the motivated individual expends effort to learn the language. That is, there is a persistent and consistent attempt to learn the material, by doing homework, by seeking out opportunities to learn more, by doing extra work, etc. Second, the motivated individual wants to achieve the goal. Such an individual will express the desire to succeed, and will strive to achieve success. Third, the motivated individual will enjoy the task of learning the language. ". There are other variables related to "motivation" including "proficiency" and "autonomy". According to Richards and Schmidt (2002: 292) language proficiency is defined as "the degree of skill with which a person can use a language, such as how well a person can read, write, speak, or understand language", while they define autonomy as "the principle that learners should be encouraged to assume a maximum amount of responsibility for what they learn and how they learn it"(p. 297). This paper will examine the role and importance of these three factors in two types of universitiesAzad and Payame Noor universities- and how these variables are related to each other. The purpose of the study is twofold: 1) to investigate the role of the independent variables such as motivation and autonomy in predicting the dependent variable of foreign language proficiency in the two different settings such as distant university of Payame Noor and Islamic Azad University. 2) to examine the possible difference between these two settings.

\subsection{Importance of the Problem}

Talking scientifically about second or foreign language learning and teaching demands knowing the influential factors related to the field. Any language learning and teaching setting comprises two important components; learner, and learning situation. In order to improve learning and teaching, it is essential to know enough about each of these 
variables. Any learner attending a learning situation brings with him a set of affective, cognitive, social and biological variables. Chastain (1988) claims that" of all the learner variables, the most influential are those related to the learners' emotions, attitudes, and personality"(p. 122), that is, the affective variables. He believes that affective variables are somehow more important than cognitive variables in developing second language skills because the emotions control the will to activate or to shut down the cognitive functions. Stevick (cited in Chastain, 1988) advocates making the development of positive attitudes in learners as the number one priority in second language classes. A learning situation includes factors related to the teacher, the course, the course materials, etc. In order to optimize learning we need to provide a context (learning situation) in which positive variables foster, while negative ones subside. Learner variables and learning context variables are in mutual relationship; they have influence on each other. In other words, one can result in another and vice versa. By doing research on these individual variables in different contexts, we can have a larger picture of learners and learning situations variables which ultimately help us better understand our learners. Considering the importance of the study, the following points can be regarded: a) The relationship between the independent variables of the study in language learning is unknown. b)There is no rich background study on the issue, and the role of autonomy in learning a second language in the distance learning setting has rarely been studies in Iran.

\section{3 background of study}

At a higher level of education in a variety of subjects, universities provide the required contexts for learning and teaching. This stresses the crucial status of context in learning and teaching. Traditional universities have long been playing their fundamental role in promoting education and knowledge, but the increasing growth of information and communication technologies in the highly competitive world from one hand, and equipping all people from all parts of the world with new developments from the other hand, have stimulated governments to find a system of education which is easy, fast, overarching and up-to-date. This led to an educational system called distance education or distance learning. According to (Rao, 2007, p.1), "Distance education is a form of education that can easily become depersonalized both for staff and students." In other words, it is a form of education in which the student is separated from his teacher in time and space but is still being guided by him (Rowntree, 1992).

With the international growth of distance education varying interpretations of what it includes have been made known. For instance, in Iran this system of education appeared with the name of Payamenoor University (PNU). To achieve its educational objectives, PNU applies new methods of education and training programs, such as open, remote or virtual education. Based on this system, neither the teacher, nor the students have control over the course materials and even over the types of examination; everything has already been determined by the educational system. Another feature of this type of university is associated with students' attendance. Here, it is not compulsory that students attend classes during the semester. In fact, courses are classified as semi-attendance and non-attendance. In semi-attendance course of study, students attend classes, but the number of times they participate a class is less than what actually happens in traditional universities. In non-attendance course of study, students do not need to attend classes at all.

Among the advantages of this system, as claimed by the system, are students-centered teaching, possibility of independence study, comprehensive coverage of materials, reduced costs and less educational requirements in terms of offering courses which need less student attendance. But the most important purpose and feature of distance training is reducing barriers related to limitations of time and space compared to traditional universities.

Learner autonomy is no longer a new idea in the history of education. Changes in the twentieth century in social sciences, psychology, philosophy, and political science have led to growth of interest in autonomy as an educational goal (Finch, 2000). There has been a proliferation of terms regarding the concept of learner autonomy in the literature, some of which are used synonymously while others are attributed a number of separate meanings. One of the earliest terms in this regard is self-directed learner; a term about which Hedge (2000) asked a group of English language teachers their impressions. Their definitions ranged from the provisional: ' It means letting students choose their own topics and activities for homework', to the passionate:' It means students' emancipation from the hands of teachers', and to the reflective: 'A self-directed learner is one who is self-motivated, one who takes the initiative, one who has a clear idea of what he wants to learn, and one who has his own plan for pursuing and achieving his goal' (p.76). Among other terms in this regard are Self-instruction, Individualized instruction, Self-Access learning, Self-direction etc (Finch, 2000). When you come across any of these terms, it is a good idea to look for what the writer means by them. The key concept that has emerged, and around which other concepts pivot, is learner autonomy as an objective for learners (Hedge, 2000). Holec (1981) perceives an autonomous learner as taking charge of his own learning. The individual has the responsibility for all the decisions regarding all aspects of learning, i.e. defining objectives, choosing materials and evaluating advancement. He considers autonomy as an ability which is not inborn but must be acquired either by natural means or by formal learning, in a systematic, deliberate way. Similarly, Dickinson (1987) defines an autonomous learner as the one who has “... complete responsibility for one's learning, carried out without the involvement of a teacher or pedagogic materials" (p. 11). In the same way, Kohonen (2003) attributes learner autonomy to learner development, arguing that the learner should be developed both as a language user and as a student. The learner needs to develop his personal awareness and self-direction, awareness of language and communication, and awareness of the learning process. Based on the related definitions and discussions on learner autonomy, this article defines an autonomous learner as a learner who: 1) is responsible for his own learning process, knowing his objectives, 2) knows how to draw on available resources independently, 3) thinks actively to learn, 4) utilizes learning strategies appropriately, and 5) has a positive attitude to achieve his goals. 
As to the relationship between autonomy and academic performance, as cited in Dafei (2007), Corno and Mandinach (1983) claimed that learner autonomy could be regarded as a factor helping learners improve their language proficiency. They drew a conclusion that autonomous learners were the learners enjoying high language proficiency. Ablard and Lipschultz (1998) also found out that high-achievement students exploited different autonomous strategies. Risenberg and Zimmerman (1992) further pointed out that those with a high degree of learner autonomy showed high scores and those with low degrees of learner autonomy exhibited low scores if learner autonomy could increase the academic scores. Similarly, Zhang and Li (2004) found that learner autonomy was closely related with the language levels. Based on her article, Dafei (2007) concluded that the students' English proficiency was significantly and positively related to their learner autonomy, and there were no significant differences among the students' learner autonomy when their English proficiency was not significantly different. But there were significant differences among the students' learner autonomy when their English proficiency was significantly different. These findings asserted that the more autonomous a learner becomes, the more likely he/she achieves high language proficiency. Similarly, Qi (2011concluded that the learner with a high degree of learner autonomy will achieve high scores, that is, showing higher language proficiency and vice verse.

In the field of foreign/second language (L2) learning, motivation has long been recognized as one of the main aspects that determines L2 achievement and attainment. According to Dörnyei (2005), motivation is considered as the primary force that generates learning and later functions as an ongoing driving impetus that helps the individual keep on acquiring a foreign language. He claims that for a learner to achieve his long-term objectives, he needs not only an appropriate curricula and good teaching, but he also requires a considerable amount on motivation, that is, without sufficient motivation, even learners with remarkable abilities likely fail to achieve their learning goals.

As one of the features of distance learning, Hurd (2008) claims that the physical absence of tutor and other students can contribute to feelings of loneliness and isolation in students which this may cause students a sense of uncertainty in their own abilities, negative comparisons with other peers and fear of failure which these can result in anxiety, demotivation and even withdrawal from the course. As cited in Hurd (2008), similarly, Ehrman (1996) stresses the affective dimension of students, emphasizing that strong motivation help students organize their skills, whereas low motivation and high anxiety interferes with their ability to utilize their skills and abilities.

Regarding the effect of motivation on academic performance, Hashemian and Heidari (2011) studied the interrelationship of autonomy, motivation, and academic performance of Persian L2 learners in distance education contexts. Their study indicated a positive and significant relationship between motivation and grade point average (GPA). Similarly, Ghanea, Zeraat Pisheh and Ghanea (2011) studied the relationship between learners' motivation (integrative and instrumental) and English proficiency among Iranian EFL learners and concluded that There was a significant relationship between the integrative motivation and instrumental motivation with English proficiency among EFL learners of Shiraz Azad University.

Taking the above issues into consideration, this study was conducted to investigate the relationship between autonomy and motivation with English language proficiency of the students in two different settings; Islamic Azad and Payamenoor universities. That is, the study, first, explored the relationship between these variables at each university, and then, compared the two university settings based on the data obtained.

Like any other field of study, this area of research needs more practice, finding further data and evidence to better understand learners, learning factors and learning contexts.

\section{Method}

\subsection{Participants}

The participants of this study, selected on the basis of their availability, were students of two different universities, Payamenoor and Azad Universities, in the city of Gonbad-e-Kavous. They were both male and female studying either in faculty of science or faculty of humanities. 152 students were studying in Azad University among which 59 were females and 93 were males (table 1). On the other hand, 98 of these students were studying in faculty of science, and 54 in faculty of humanities. With regard to Payamenoor University, 144 students were studying; 93 were females and 51 were males. 68 of these students were studying in faculty of science, while 76 in faculty of humanities.

Table 1. Participants of the study

\begin{tabular}{llllll}
\hline University & female & male & Faculty of Humanity & Faculty of Science & total \\
\hline Payamenoor & 93 & 51 & 76 & 68 & 144 \\
\hline Azad & 59 & 93 & 54 & 98 & 152 \\
\hline
\end{tabular}

\subsection{Instruments}

To collect the required data a questionnaire consisting of four sections was provided. In the first section of the questionnaire, bio-data information, the participants needed to include information about their gender, university and major of study. Three data collection instruments formed the other sections of the questionnaire; the second section of it was comprised of items regarding English language proficiency of the participants; the third section dealt with the items 
about the motivation of the individuals toward English language; and the fourth section was about the items concerning autonomy of the students in learning.

\subsubsection{Language self-assessment questionnaire}

As a means of documenting and charting student growth in the four language skills (listening, speaking, reading, and writing), self-rated proficiency ratings on the Sung Language Assessment Questionnaire were used. There are four subscales of the four blocks of items [speaking, listening, reading and writing], each one comprising 10 items. In regard to the internal reliability of the questionnaire, Cronbach alpha turned out to be 0.954 in Azad University and 0.933 in Payamenoor University.

\subsubsection{Attitude motivation test battery}

This is a large battery of tests which measures a number of different aspects of language learning. This instrument was originally devised to measure attitudes of students studying English and French in Canada. Scales were consisted of attitudes toward French Canadians, interest in foreign languages, attitudes toward European French people, attitudes toward learning French, integrative orientation, instrumental orientation, anxiety, parental encouragement, motivational intensity, and desire to learn French. The Integrative and Instrumental Orientation scales of the original 7-point Likert Scale format of Gardner's Attitude/Motivation Test Battery (AMTB) (Gardner, 1985) were adapted to a 5-point scale, ranging from 'Strongly Agree' to 'Strongly Disagree'. The AMTB is reported to have good reliability and validity (Gardner, 1985; Gardner and Smythe, 1981) and the internal consistency estimate of reliability for the modified questionnaire was calculated, and Cronbach's Alpha in Azad university was recorded 0.854, while in Payamenoor it was calculated 0.863.The questionnaire used in this study was developed (modified) by Ghorbandordinejad (2011). It was adapted to a 4-point scale, ranging from 'Strongly Agree' to 'Strongly Disagree'. The questionnaire was provided for the participants in Persian, that is, in their spoken language.

\subsubsection{Learner autonomy questionnaire}

In order to gather the required data the Learner Autonomy Questionnaire developed by Kashefian (2002) was employed. This questionnaire consists of 40 items in a 5-point Likert scale, ranging from "Strongly agree" to "Strongly disagree", all of which about the role and significance of autonomy in L2 learning. As to the internal reliability of the questionnaire, Cronbach alpha was calculated 0.925 in Azad University, and 0.893 in Payamenoor University. For the validity, it was looked into by some professors of Shahrekord and Shiraz Universities and confirmed to be valid for the purpose of the present study (Hashemian and Heidari, 2011).

\subsection{Procedure}

To collect the required data, the researcher needed to distribute the abovementioned questionnaire among the students of the two universities, Azad and Payamenoor. The first step to do so was to ask authorities to cooperate closely with the researcher. The second step was to distribute the questionnaire among the students. The purpose and concept of the questionnaire were explained before the distribution. During the completion process of the questionnaire, the researcher was present physically to monitor and also to help the participants understand the parts. There was no time limit for the respondents to complete the questionnaire and they were assured that the information they gave would be kept confidential and be used for research purposes only.

\subsection{Procedure}

This study is a cross-sectional survey in nature, because it focuses on major variables of higher education teaching and learning environment to gather information on a population at a single point in time. It is also a survey research design because the participants were surveyed on two individual different variables of academic setting. Further, a post hoc correlation design was applied as a framework for data analysis in the study. Thus the relationship among the variables were explored (rather than manipulated) in an attempt to develop a model for examining the relationship among key variables of the study.

\subsection{Data analysis}

In this research, both quantitative and qualitative methods were applied to analyze the data. In order to investigate the research hypotheses, both descriptive and inferential statistics were used for different purposes. Descriptive statistics such as means and standard deviations were used in order to check the underlying assumptions of the statistical procedures applied in the study. For the purpose of testing the hypotheses, inferential statistical procedures were applied. To test the first two hypotheses, Multiple Regression Analysis was used to predict the variance in the dependent variable (i.e., foreign language proficiency) from the variance in the independent variables (i.e., autonomy and motivation). While to test the third hypothesis, Fisher $r$ to $\mathrm{z}$ transformation was applied to investigate the probable relationship between motivation along with autonomy and the performance of the participants.

\section{Results}

In the output table 2, descriptive statistics provides the information concerning our variables taken from 152 Azad University students. The variables motivation, autonomy and proficiency have the mean of 117.55, 92.51 and 116.63 with the standard deviation of, and 16.60, 30.18 and 28.39respectively. Table 2 shows the descriptive statistics for Payamenoor University taken from 144 students. The variables motivation, autonomy and proficiency have the mean of 111.47, 93.42 and 110.33 with the standard deviation of $16.57,24.65$ and 25.62 respectively. The information comes from 144 respondents, the mean of 110.33 and standard deviation of 25.62 . 
Table 2. Descriptive Statistics of Variables in Payamenoor University

\begin{tabular}{llll}
\hline \multicolumn{1}{c}{ Mean } & \multicolumn{1}{c}{ Std. Deviation } & $\mathrm{N}$ \\
\hline motivation & 111.4792 & 16.57826 & 144 \\
autonomy & 93.4236 & 24.65810 & 144 \\
proficiency & 110.3333 & 25.62478 & 144 \\
\hline
\end{tabular}

Table 3. Descriptive Statistics of Variables in Azad University

\begin{tabular}{llll}
\hline \multicolumn{1}{c}{ Mean } & \multicolumn{1}{c}{ Std. Deviation } & $\mathrm{N}$ \\
\hline motivation & 116.6382 & 28.39820 & 152 \\
autonomy & 92.5132 & 30.18881 & 152 \\
proficiency & 116.6382 & 28.39820 & 152 \\
\hline
\end{tabular}

Multiple regression is one of the fussier of the statistical techniques. It makes a number of assumptions about the data, and it is not all that forgiving if they are violated (Pallant, 2007).

The major assumptions are:

For stepwise regression, there should be a ratio of 40 cases for every independent variable (Tabachnick and Fidell, 2007, p.123 as cited in Pallant, 2007, p. 148). It was adequately met in this study since the sample of both universities exceeds the minimum required size of 80 (40 x 2 independent variables).

The correlations between the variables in our model for Azad University are provided in the following table 4. In this case both of the scales (motivation and autonomy) correlate substantially with proficiency (.33 and 58 respectively). The least relationship among the independent variables and dependent variables is above .3 preferably. Also the correlation between each of our independent variables is not high. It should not be more than .7. Table 5 shows that the correlation between these two independent (motivation and autonomy) is -.106 which is less than .7.

Table 4. Correlations between Variables of Payamenoor University

\begin{tabular}{|c|c|c|c|c|}
\hline & & motivation & autonomy & proficiency \\
\hline \multirow[t]{3}{*}{ Pearson Correlation } & motivation & 1.000 & $-.276 * *$ & $.320 * *$ \\
\hline & autonomy & $-.276 * *$ & 1.000 & -.004 \\
\hline & proficiency & $.320 * *$ & -.004 & 1.000 \\
\hline \multirow[t]{3}{*}{$\mathrm{N}$} & motivation & 144 & 144 & 144 \\
\hline & autonomy & 144 & 144 & 144 \\
\hline & proficiency & 144 & 144 & 144 \\
\hline
\end{tabular}

$* * \mathrm{p}<.01$

Table 5. Correlations between Variables of Azad University

\begin{tabular}{lllll}
\hline & & motivation & autonomy & proficiency \\
\hline Pearson Correlation & motivation & 1.000 & -.106 & $.336^{* *}$ \\
& autonomy & -.106 & 1.000 & $.149^{*}$ \\
& proficiency & $.336^{* *}$ & $.149^{*}$ & 1.000 \\
$\mathrm{~N}$ & motivation & 152 & 152 & 152 \\
& autonomy & 152 & 152 & 152 \\
& proficiency & 152 & 152 & 152 \\
$* \mathrm{p}<.05$ & & & \\
$* * \mathrm{p}<.01$ & & &
\end{tabular}

In the case of Payamenoor University, the correlations between the variables in the model for are provided in the following table. In this case both of the motivation scales (.32) correlate substantially, but autonomy (.004) does not correlate with proficiency. The least relationship among the independent variables and dependent variables is above .3 preferably. Also the correlation between each of our independent variables is not high. It should not be more than .7. Table 6 shows that the correlation between these two independent (motivation and autonomy) is -.276 which is less than .7. 
Table 6. Correlations - Payamenoor University

\begin{tabular}{lllll}
\hline & & motivation & autonomy & proficiency \\
\hline Pearson Correlation & motivation & 1.000 & -.276 & .320 \\
& autonomy & -.276 & 1.000 & -.004 \\
& proficiency & .320 & -.004 & 1.000 \\
\hline Sig. (1-tailed) & motivation &. & .000 & .000 \\
& autonomy & .000 &. & .480 \\
& proficiency & .000 & .480 &. \\
\hline $\mathrm{N}$ & motivation & 144 & 144 & 144 \\
& autonomy & 144 & 144 & 144 \\
& proficiency & 144 & 144 & 144 \\
\hline
\end{tabular}

In the coefficient table of Azad University (table 7), there are two values of tolerance and Variance Inflation Factor (VIF). The tolerance value of less than .10, or a VIF value of above 10 will cause multicollinearity problem. In the table below, the tolerance value for each independent variable is .989 , which is not less than .10; therefore, we have not violated the multicollinearity assumption. This is also supported by the VIF value, which is 1.000 , which is well below the cut-off of 10 .

In the coefficient table of Payamenoor University (table 8), there are also two values of tolerance and Variance Inflation Factor (VIF). The tolerance value for the independent variable (motivation) is 1.000, which is not less than .10; therefore, we have not violated the multicollinearity assumption. This is also supported by the VIF value, which is 1.000 , which is well below the cut-off of 10 .

Table 7. Coefficients ${ }^{\mathrm{a}}-$ Azad University

\begin{tabular}{|c|c|c|c|c|c|c|c|c|c|c|c|}
\hline & \multirow[b]{2}{*}{ Model } & \multicolumn{2}{|c|}{$\begin{array}{c}\text { Unstandardized } \\
\text { Coefficients }\end{array}$} & \multirow{2}{*}{$\begin{array}{c}\begin{array}{c}\text { Standardized } \\
\text { Coefficients }\end{array} \\
\text { Beta }\end{array}$} & \multirow[b]{2}{*}{$\mathrm{t}$} & \multirow[b]{2}{*}{ Sig. } & \multicolumn{3}{|c|}{ Correlations } & \multicolumn{2}{|c|}{ Collinearity Statistics } \\
\hline & & B & Std. Error & & & & Zero-order & Partial & Part & Tolerance & VIF \\
\hline \multirow[t]{2}{*}{1} & (Constant) & 49.132 & 15.611 & & 3.147 & .002 & & & & & \\
\hline & motivation & .574 & .131 & .336 & 4.367 & .000 & .336 & .336 & .336 & 1.000 & 1.000 \\
\hline \multirow[t]{3}{*}{2} & (Constant) & 28.881 & 17.431 & & 1.657 & .100 & & & & & \\
\hline & motivation & .608 & .130 & .356 & 4.675 & .000 & .336 & .358 & .354 & .989 & 1.011 \\
\hline & autonomy & .176 & .072 & .187 & 2.455 & .015 & .149 & .197 & .186 & .989 & 1.011 \\
\hline
\end{tabular}

a. Dependent Variable: proficiency

Table 8. Coefficients ${ }^{\mathrm{a}}$ - Payamenoor University

\begin{tabular}{|c|c|c|c|c|c|c|c|c|c|c|c|}
\hline & \multirow[b]{2}{*}{ Model } & \multicolumn{2}{|c|}{$\begin{array}{c}\text { Unstandardized } \\
\text { Coefficients }\end{array}$} & \multirow{2}{*}{$\begin{array}{c}\begin{array}{c}\text { Standardized } \\
\text { Coefficients }\end{array} \\
\text { Beta }\end{array}$} & \multirow[b]{2}{*}{$\mathrm{t}$} & \multirow[b]{2}{*}{ Sig. } & \multicolumn{3}{|c|}{ Correlations } & \multicolumn{2}{|c|}{ Collinearity Statistics } \\
\hline & & $\mathrm{B}$ & Std. Error & & & & Zero-order & Partial & Part & Tolerance & VIF \\
\hline 1 & $\begin{array}{r}\text { (Consta } \\
n t)\end{array}$ & & 13.848 & & 3.982 & .000 & & & & & \\
\hline & $\begin{array}{r}\text { motivati } \\
\text { on }\end{array}$ & & .123 & .320 & 4.029 & .000 & .320 & .320 & .320 & 1.000 & 1.000 \\
\hline
\end{tabular}

a. Dependent Variable: proficiency

To test for normality, skewness and kurtosis of the distribution should be between -1.0 and +1.0. Tables 9 and 10 show the skewness and kurtosis values for all variables satisfied the criteria for a normal distribution.

Table 9. Skewness and Kirtosis values for all variables in Payamenoor University

\begin{tabular}{|c|c|c|c|c|}
\hline & \multicolumn{2}{|c|}{ Skewness } & \multicolumn{2}{|r|}{ Kurtosis } \\
\hline & Statistic & Std. Error & Statistic & Std. Error \\
\hline motivation & -.321 & .201 & .699 & .400 \\
\hline autonomy & .528 & .201 & .862 & .400 \\
\hline proficiency & -.047 & .201 & -.692 & .399 \\
\hline
\end{tabular}


Table 10. Skewness and Kirtosis values for all variables in Azad University

\begin{tabular}{|c|c|c|c|c|}
\hline & \multicolumn{2}{|c|}{ Skewness } & \multicolumn{2}{|r|}{ Kurtosis } \\
\hline & Statistic & Std. Error & Statistic & Std. Error \\
\hline motivation & -.343 & .196 & .481 & .390 \\
\hline autonomy & .759 & .197 & .118 & .391 \\
\hline proficiency & -.506 & .196 & -.493 & .390 \\
\hline
\end{tabular}

The first question of this study was:

Q1: Do Motivation and Autonomy predict foreign language proficiency among students in Payamenoor University?

To explore the contributions of the factors of motivation and autonomy to the foreign language proficiency a stepwise multiple regression analysis was conducted. The results of this analysis are provided in tables 11 and 12 . In this analysis, language learning motivation and language learning autonomy were predictors and students' foreign language proficiency was the criterion variable.

Table 11. Variables Entered/Removeda Pyamenour

\begin{tabular}{|c|c|c|c|}
\hline Model & $\begin{array}{l}\text { Variables } \\
\text { Entered }\end{array}$ & $\begin{array}{l}\text { Variables } \\
\text { Removed }\end{array}$ & Method \\
\hline 1 & motivation & & $\begin{array}{l}\text { Stepwise (Criteria: Probability-of-F-to-enter }<= \\
.050 \text {, Probability-of-F-to-remove }>=.100) .\end{array}$ \\
\hline
\end{tabular}

a. Dependent Variable: proficiency

Table 12. Model Summaryb Pyamenour

\begin{tabular}{llllc}
\hline Model & $\mathrm{R}$ & $\mathrm{R}$ Square & $\begin{array}{c}\text { Adjusted R } \\
\text { Square }\end{array}$ & Std. Error of the Estimate \\
\hline 1 & $.320^{\mathrm{a}}$ & .103 & .096 & 24.36005 \\
\hline \\
$\begin{array}{l}\text { a. Predictors: (Constant), motivation } \\
\text { b. Dependent Variable: proficiency }\end{array}$
\end{tabular}

Table 12. shows that model one (i.e. motivation) can best predict the dependent variable. The value of correlation ( $\mathrm{r}=$ .320) shows that motivation alone accounts for about $10 \%$ of the variation and to explore that this value is significant, we analyze the ANOVA, because the value of $F=16.23$, in the level of $p<0.01$ is significant; it means that $11 \%$ of the variation is the ratio is based on motivation (table 12).

Table 13 reveals that motivation is alone the predictor of proficiency and autonomy can not predict proficiency in Payamenoor University.

Table 13. ANOVA ${ }^{\mathrm{b}}$ Pyamenour

\begin{tabular}{|c|c|c|c|c|c|c|}
\hline & Model & $\begin{array}{l}\text { Sum of } \\
\text { Squares }\end{array}$ & $\mathrm{df}$ & Mean Square & $\mathrm{F}$ & Sig. \\
\hline \multirow[t]{3}{*}{1} & Regression & 9633.463 & 1 & 9633.463 & 16.234 & $.000^{\mathrm{a}}$ \\
\hline & Residual & 84264.537 & 142 & 593.412 & & \\
\hline & Total & 93898.000 & 143 & & & \\
\hline
\end{tabular}
a. Predictors: (Constant), motivation
b. Dependent Variable: proficiency

A stepwise Multiple Regression was conducted to evaluate whether both motivation and autonomy were necessary to predict students' proficiency. At step 1 of the analysis motivation entered into the regression equation and was significantly related to proficiency $(1,142)=16: 234, p<.001$. The multiple correlation coefficient was .320, indicating approximately $10.3 \%$ of the variance of the proficiency could be accounted for by motivation. Autonomy scores did not enter into the equation at step 2 of the analysis $(\mathrm{t}=1.100, \mathrm{p}>.05)$. Thus the regression equation for predicting proficiency was: $\mathrm{Y}=55.141+.495(\mathrm{X})$

The second question of this study was: 
Q2: Do Motivation and Autonomy predict foreign language proficiency among students in Azad University?

Another stepwise multiple regression analysis was conducted to evaluate how well the motivation and autonomy predicted students' foreign language proficiency in Azad University.

Table 14 shows that model one (i.e. motivation) can best predict the dependent variable. The value of correlation ( $\mathrm{r}=$ .336) shows that motivation alone accounts for about $11 \%$ of the variation and to explore that this value is significant, we analyze the ANOVA, because the value of $F=19.06$, in the level of $p<0.01$ is significant, it means that $11 \%$ of the variation is the ratio is based on motivation (table 15).

Table 15 reveals that model 2 (i.e. autonomy) together with motivation accounts for about $13.5 \%$ the variation and this value is significant $(\mathrm{F}=12.86, \mathrm{p}<0.01)$.

Table 14. Variables Entered/Removed ${ }^{\mathrm{a}}$ Azad

\begin{tabular}{|c|c|c|c|}
\hline Model & $\begin{array}{l}\text { Variables } \\
\text { Entered }\end{array}$ & $\begin{array}{l}\text { Variables } \\
\text { Removed }\end{array}$ & Method \\
\hline 1 & motivation & & $\begin{array}{l}\text { Stepwise (Criteria: Probability-of-F-to-enter }<=.050 \text {, } \\
\text { Probability-of-F-to-remove }>=.100 \text { ). }\end{array}$ \\
\hline 2 & autonomy & & $\begin{array}{l}\text { Stepwise (Criteria: Probability-of-F-to-enter }<=.050 \text {, } \\
\text { Probability-of-F-to-remove }>=.100 \text { ). }\end{array}$ \\
\hline
\end{tabular}

a. Dependent Variable: proficiency

Table 15. Model Summary ${ }^{\mathrm{c}}$ Azad

\begin{tabular}{lllll}
\hline Model & R & R Square & Adjusted R Square & Std. Error of the Estimate \\
\hline 1 & $.336^{\mathrm{a}}$ & .113 & .107 & 26.83781 \\
2 & .384 & .147 & .136 & 26.39890 \\
\hline
\end{tabular}

a. Predictors: (Constant), motivation

b. Predictors: (Constant), motivation, autonomy

c. Dependent Variable: proficiency

It can be seen in table 16 that model one is statistically significant $[\mathrm{F}(1,19.06)]$

Table 16. ANOVA ${ }^{\mathrm{c}}$ Azad

\begin{tabular}{ccccccc}
\hline & & Sum of Squares & df & Mean Square & F & Sig. \\
\hline 1 & Regression & 13734.917 & 1 & 13734.917 & 19.069 & $.000^{\mathrm{a}}$ \\
& Residual & $1.080 \mathrm{E} 5$ & 150 & 720.268 & & \\
& Total & $1.218 \mathrm{E} 5$ & 151 & & $.000^{\mathrm{b}}$ \\
\hline 2 & Regression & 17936.705 & 2 & 8968.352 & 12.869 & \\
& Residual & $1.038 \mathrm{E} 5$ & 149 & 696.902 & & \\
& Total & $1.218 \mathrm{E} 5$ & 151 & & & \\
\hline
\end{tabular}
a. Predictors: (Constant), motivation
b. Predictors: (Constant), motivation, autonomy
c. Dependent Variable: proficiency

A Stepwise Multiple Regression was conducted to evaluate whether both motivation and autonomy were necessary to predict students' proficiency. At step 1 of the analysis motivation entered into the regression equation and was significantly related to proficiency $(1,150)=19: 069, \mathrm{p}<.001$. The multiple correlation coefficient was .336, indicating approximately $11.3 \%$ of the variance of the proficiency could be accounted for by motivation. At step 2 of the analysis regarding autonomy, autonomy entered into the regression equation and was significantly related to proficiency $(2,149)$ $=12.869, \mathrm{p}<.001$. The multiple correlation coefficient was .384 , indicating approximately $14.7 \%$ of the variance of the proficiency could be accounted for by autonomy. Thus the regression equation for predicting proficiency was: $\mathrm{Y}=$ $28.881+608(\mathrm{X} 1)+176(\mathrm{X} 2)$ 
The third question of this study was:

Q3: Is there any difference between students' motivation, autonomy and foreign language learning proficiency of Payamenoor University and Azad University?

Fisher's $r$ to $\mathrm{z}$ transformation was used to calculate confidence for the intervals on the difference between correlations of these two environments.

$$
\begin{aligned}
& z=\frac{z r 1-z r 2}{\sqrt{\frac{1}{n 1-3}+\frac{1}{n 2-3}}} \\
& z=\frac{.332-.4061}{\sqrt{\frac{1}{144-3}+\frac{1}{152-3}}} \\
& z=\frac{-.074}{\sqrt{\frac{1}{141}+\frac{1}{149}}} \\
& z=\frac{-.074}{\sqrt{.0071+.0067}} \\
& z=\frac{-.074}{\sqrt{. .1175}} \\
& z=-.6298
\end{aligned}
$$

Because the value of $Z$ is lower than $Z=1.96$, we accept the null hypothesis. That is to say, there is no significance between these two correlations. The value of correlation is equal between Payamenoor and Azad universities; however, the predictions are different.

\section{Discussion}

The main objective of this study was to explore the possible relationship among learner autonomy, motivation and foreign language proficiency in two universities of different settings; the first one was Payamenoor University as a distance university and the other one was Islamic Azad universities as a traditional university. With regard to motivation, the study revealed that there is a positive and significant relationship between motivation and foreign language proficiency in both universities. This finding is in line with Hashemian and Heidari (2011) who studied the interrelationship of autonomy, motivation, and academic performance of Persian L2 learners in distance education contexts. Their study showed a positive and significant relationship between motivation and GPA. In line with this, White (1995, cited in Hashemian and Heidari, 2011) also concluded that motivation plays a crucial role in L2 learners' success in a distance context. Gardner and Lambert (1972) further noted that interactively oriented individuals achieve greater L2 competence. However, there are some studies that show the opposite of this finding. For example, Madileng (2007) investigated the relationship between motivation and English second language proficiency among first year NIC students at Ekurhuleni West College which the results showed no significant correlation between these two variables.

In regard to autonomy, the study showed opposite results between two universities. In Payamenoor University, there was no significant correlation between students' autonomy and their foreign language proficiency, while in Azad University, the study revealed a positive relationship between these two factors. There are some studies that show the opposite of this finding. Hashemian and Heidari (2011) concluded that there is a positive and significant relationship between autonomy and GPA. In line with this finding, the reports given by Grove, Wasserman, and Grodner (2006) cited in Hashemian and Heidari (2011) on the relationship between GPA scores and autonomy indicated a positive significant relationship between the two variables. Dafei (2007) also concluded that to foster the students' learner autonomy in the classroom or in the relevant training programs in second or foreign language teaching and learning might help improve the students' English proficiency. He inferred that the more autonomous a learner becomes, the more likely he achieves high language proficiency. This finding also confirms the ideas of the randomized controlled survey conducted by Zhang and $\mathrm{Li}$ (2004) who concluded that learner autonomy was intimately connected to the language levels and its Pearson Coefficient amounted to 0.6088 on the basis of the comparison between the subjects in China and Europe. The hypothesis of Corno and Mandinach (1983) confirms with empirical evidence that learner autonomy could help enhance the learners' proficiency and the autonomous learners were the learners of high proficiency.

The aim of education is to help learners succeed in their learning. Learning does not just refer to educational contexts but to all aspects of individuals' life. Therefore, learners should be aware of and develop skills and strategies which help them manage their affairs and to take responsibility for their own learning; in short, to develop autonomy. Learner autonomy, along with learners' motivation, is one of the most important factors enhancing learners in learning in all subjects of study, for success in education needs learners' own efforts and investment of time and energy. 


\section{Conclusion}

The main objectives of this study were to explore the possible relationship among learner autonomy, motivation and English language proficiency. It was noted that taking these variables into consideration will make a valuable contribution in the teaching and learning of every language. With regard to Payamenoor University, the study revealed that there is a positive and significant relationship between motivation and English language proficiency. But regarding autonomy, no significant or meaningful relationship between autonomy and English language proficiency was observed. This might be due to factors as: 1) it is easier to pass Payamenoor universities' entrance examination than Azad universities', thus students of lower aptitude attend Payamenoor universities. 2) As Payamenoor students do not need to attend classes or the number times they attend their classes is a few, therefore they resort to the way they would behave at school, to be passive in learning and perceive the teacher as the source of knowledge who would provide them what they needed. Thus, at university as their new educational context, they do not take responsibility in learning and play a passive role enjoying no or less autonomy.

With regard to Azad University, the study indicated a positive and significant relationship between motivation and English language proficiency. The study also showed that a positive and significant relationship between autonomy and English language proficiency. This might be due to factors as: 1) unlike Payame Noor students, students of higher aptitude can pass Azad universities' entrance examination. 2) Since attending classes is compulsory during the semester, the students become familiar with universities' educational system and environment, understanding that learning is on their shoulders, not teacher's mission, and that they have to be responsible and show autonomy in their learning.

The findings of this study support the conclusion that in Iran, traditional education setting is more effective than distance education setting in fostering individuals' learning strategies and skills in learning. To improve the quality of distance education context entails arranging classes for students to learn and enhance the strategies needed in learning.

\section{References}

Ablard, K. E., \& Lipschultz, R. E. (1998). Self-regulated learning in high-achieving students: Relations to advanced reasoning, achievement goals, and gender. Journal of Educational Psychology, 90, 94-101.

Corno, L. \& Mandinach, E. B. (1983). The role of cognitive engagement in classroom learning and motivation. Educational Psychologist, 18, 88-108.

Dafei, D. (2007). An Exploration of the Relationship between Learner Autonomy and English Proficiency. Professional Teaching Articles. Retrieved from www.asian-efl-journal.com/pta_Nov_07_dd.pdf

Dickinson, L. (1987). Self-instruction in language learning. Cambridge: Cambridge University Press.

Dörnyei, Z. (2005). The psychology of the language learner: Individual differences in second language acquisition. London: Lawrence Erlbaum associates.

Ehrman, M.E. (1996). Understanding Second Language Learning Difficulties. Sage, Thousand Oaks, CA.

Finch, A. E. (2000). A formative evaluation of a task-based EFL programme for Korean university students. Unpublished Ph.D. Thesis. Manchester University, U.K. Retrieved February 25, 2006 from http://www.finchpark.com/afe/index.htm

Gardner, R. C. (1985). The Attitude/Motivation Test Battery: Technical Report. London, ON: Univ. of Western Ontario. Retrieved from publish.uwo.ca/ gardner/docs/AMTBmanual.pdf.

Gardner, R. C., \& Smythe, P. C. (1981). On the development of the attitude/motivation test battery. Canadian Modern Language Review, 37, 510-525.

Ghanea. M., Zeraat Pisheh, H. R. \& Ghanea, M. H. (2011). The Relationship between Learners' Motivation (Integrative and Instrumental) and English Proficiency among Iranian EFL Learners. World Academy of Science, Engineering and Technology 592011.

Grove, W. A., T. Wasserman, and A. Grodner. (2006). Choosing a proxy for academic aptitude. Journal of Economic Education 37 (Spring): 131-48.

Hashemian, M. \& Heidari, K. (2011). The Interrelationship of Autonomy, Motivation, and Academic Performance of Persian L2 Learners in Distance Education Contexts. Theory and Practice in Language Studies, Vol. 1, No. 4, pp. 319326, April 2011. doi:10.4304/tpls.1.4.319-326.

Hedge, T. (2000). Teaching and Learning in the Language Classroom. Oxford: Oxford University Press.

Holec, H. (1981). Autonomy and foreign language learning. Oxford: Pergamon. (First published [1979], Strasbourg: Council of Europe).

Hurd, S. (2008). Investigating affect in a distance language learning context: approaches and methods. RTVU ELT Express, China, 21(2).

Kashefian, S. N. (2002). An investigation into college EFL learners' beliefs demonstrating their predispositions Towards learner autonomy. Unpublished master's thesis, Shiraz University, Shiraz. 
Kohonen, V. (2003). Student autonomy and the teacher's professional growth: Fostering a collegial school culture in language teacher education. In Inozu, J. (2011). Developing learner autonomy in the language class in Turkey: voices from the classroom. Asia Pacific Educ. Rev. (2011) 12:523-531. doi: 10.1007/s12564-011-9154-0

Madileng, M. M. (2007). English as a medium of instruction: The relationship between motivation and English second language proficiency. Retrieved from uir.unisa.ac.za/xmlui/bitstream/handle/10500/.../dissertation.pdf?...1

Pallant, J. (2007). SPSS Survival Analysis. Crows Nest: Allen \& Unwin.

Qi, A. (2011). On the Relationships between Learner Autonomy and Language Proficiency: An Investigation of Chinese English Majors. Energy Procedia 13 (2011) 9976 - 9982. Retrieved from www.asian-efljournal.com/pta_Nov_07_dd.pdf

Rao, V. K. (2007). Distance Education. S.B.Nangia. A.P.H. Publishing Corporation. Retrieved from http://books.google.com/books?id=GSVMX2BITWcC\&printsec=frontcover\&dq=distance+education\&source=bl\&ots= 2ELR4buJWp\&sig=dH6LGS5QTyHgHAJW8EDo5a8YeM\&hl=en\&sa=X\&ei=5G9ZUNqmIMe5hAfkn4HgBw\&ved=

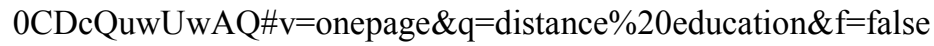

Risenberg, R. \& Zimmerman, B.J. Self-regulated learning in gifted students. Roper Revies, no.15, pp. 98-100, 1992. In Qi, A. (2011). On the Relationships between Learner Autonomy and Language Proficiency: An Investigation of Chinese English Majors. Energy Procedia 13 (2011) 9976 - 9982. Retrieved from www.asian-efljournal.com/pta_Nov_07_dd.pdf

Rowntree, D. (1992). Exploring Open and Distance Learning. Retrieved from http://books.google.com/books?id=HQIToS9ciEC\&printsec=frontcover\&dq=exploring + open + and + distance + learning + by+Derek+Rowntree\&hl=en\&sa=X\&ei=1OyXUK26F8LJrAfSiIDwAQ\&ved=0CCsQ6AEwAA

Tabachnick, B. G., \& Fidell, L. S. (2007). Using multivariate statistics (5th ed.). Upper Saddle River, NJ: Pearson Allyn \& Bacon.

Zhang, L.X. \& Li X.X. (2004). A comparative study on learner autonomy between Chinese students and west European students. Foreign Language World, 4, 15-23. 